\title{
ETIKA KERJA ISLAM SEBAGAI VARIABEL INTERVENING ANTARA INTERNAL LOCUS OF CONTROL DENGAN ROLE CONFLICT KARYAWAN WANITA BERHIJAB
}

\author{
Dewi Nuraini \\ dewintanada@gmail.com \\ Program Studi Manajemen - Fakultas Ekonomi \\ Universitas Wijaya Kusuma Surabaya
}

\begin{abstract}
The purpose of this study is to determine and explain the significance of the influence of Internal Locus of Control on Role Conflict with the ethics of Islamic work as intervening variable relationship. The type of research used in this research is explanatory research with quantitative research method. In this study using 3 (three) variables of internal locus of control as free variables, Islamic work ethics as intervening and role conflict variables as dependent variables. Where respondents in this study as many as 92 female respondents berhijab.

This study uses statistical analysis regression path analysis method using SPSS 16 for windows and sobel test. To see the effect of mediation or intervening. Based on the results of the analysis show that the four hypotheses submitted accepted the truth, but the relationship between ethical work of Islam and positive role conflict in this study.
\end{abstract}

Keywords: Internal locus of control, Islamic work ethic, role conflict.

\section{PENDAHULUAN}

Kesuksesan sebuah organisasi sangat tergantung pada manusia. Manusia adalah penentu kesuksesan atau kegagalan. Konsekuensinya diberikan pada faktor-faktor yang mempengaruhi perubahan. Salah satu faktor yang mempengaruhi perubahan adalah etika mereka pada oganisasi . Menurut (Mas'ud, 2002) Etika diterjemahkan menjadi kesusilaan karena sila berarti dasar, kaidah, atau aturan, su berarti baik, benar dan bagus. Etika didalam organisasi disebut etika kerja. Perusahaan dengan etika kerja yang baik akan memiliki dan mengamalkan nilai-nilai, yakni : kejujuran, keterbukaan, loyalitas kepada perusahaan, konsisten pada keputusan, dedikasi kepada stakeholder, kerja sama yang baik, disiplin, dan bertanggung jawab.

McCuddy dan Peery (1996) berpendapat bahwa individu yang beretika baik memiliki locus of control internal lebih tinggi dibanding dengan locus of control external. Menurut Martin (1976) dan Rokeach (1968) dalam Ghozali (2002) hubungan antara tingkat religiusitas dan sikap karyawan dapat dijelaskan dari sudut pandang teori personality yang dinyatakan bahwa tingkat religiusitas akan menjadi bagian dari identitas diri seseorang (personality). 
Ahmad Janan Asifudin (2004), Etos kerja dalam perspektif Islam diartikan sebagai pancaran dari kaidah yang bersumber dari pada sistem keimanan Islam yakni, sebagai sikap hidup yang mendasar berkenaan dengan kerja, sehingga dapat dibangun paradigma etos kerja yang islami.

Etika kerja islam menekankan kreatifitas kerja sebagai sumber kebahagian dan kesempurnaan. Kerja keras merupakan kebajikan, dan mereka yang bekerja keras lebih mungkin maju dalam kehidupan, sebaliknya tidak bekerja keras merupakan sumber kegagalan dalam kehidupan (Ali, 1998). Dengan adanya perbedaan cara pandang saja bisa menimbulkan konflik terlebih lagi bagi wanita yang berkeluarga skaligus bekerja.

Menurut Rizzo et al., (1970) dalam Yousef (2000) menyatakan bahwa Role conflict yang didefinisikan sebagai ketidak sesuaian dalam peran yang telah dikomunikasikan sehingga berbenturan dengan peran yang di jalankan. Selanjutnya, dengan etika kerja islam yang tinggi diharapkan karyawan wanita berhijab bisa merasakan kenyamanan dalam bekerja sebagai SPG event serta dapat mengurangi konflik peran yang mereka jalani baik sebagai SPG sekaligus wanita berumahtangga.

\section{Internal Locus of Control}

Menurut Robbins (2007:102) "internal locus of control adalah seseorang yakin bahwa mereka merupakan pemegang kendali atas apapun yang terjadi pada diri mereka". Internal locus of control terjadi bila seseorang percaya bahwa dirinya adalah tuan dari nasibnya sendiri.

Menurut Rotter (dalam Zulkaida, 2007) individu dengan internal locus of control cenderung menganggap bahwa keterampilan (skill), kemampuan (ability), dan usaha (efforts) lebih menentukan pencapaian dalam hidup mereka.

\section{Etika Kerja Islam}

Menurut Ahmad.S. et.al mendefinisikan etika kerja Islam sebagai berikut:

"Islamic Work Ethics as a set of value or system of beliefs derived from the Qur'an and Sunnah concerning work and hard work." Etika kerja Islam adalah sebagai seperangkat nilai atau sistem kepercayaan yang diturunkan dari Al-Qur'an dan Sunnah / Hadist mengenai kerja dan kerja keras.

Ali dalam Fitria (2003) menegaskan bahwa nilai kerja dalam etika kerja yang islami lebih bersumber pada niat daripada hasil kerja. Nasr dalam Yousef (2000) menegaskan bahwa etika kerja yang islami patut mendapat penyelidikan yang serius karena merupakan hal yang ideal dimana muslim mencoba untuk mewujudkan

\section{Role Conflict}

Role conflict didefinisikan sebagai "ketidak sesuaian dalam peranan yang telah dikomunikasikan sehingga berbenturan dengan peran yang dijalankan" (Rizzo et al., 1970) dalam Yousef (2000). Seniati (2002) dalam Desiana dan Soetjipto (2006) mengemukakan "role conflict diartikan sebagai tingkat dimana performa dianggap dipengaruhi oleh tekanan-tekanan yang 
mengakibatkan munculnya konflik atau tingkah laku yang saling bertentangan".

\section{Tujuan Penelitian}

1. Untuk mengetahui dan menganalisis apakah internal locus of control berpengaruh signifikan terhadap role conflict karyawan wanita berhijab

2. Untuk mengetahui dan menganalisis apakah internal locus of control berpengaruh signifikan terhadap etika kerja islam karyawan wanita berhijab

3. Untuk mengetahui dan menganalisis apakah etika kerja Islam berpengaruh signifikan terhadap role conflict karyawan wanita berhijab

4. Untuk mengetahui dan menganalisis apakah internal locus of control berpengaruh signifikan terhadap role conflict karyawan wanita berhijab melalui etika kerja islam sebagai variabel intervening

\section{METODE PENELITIAN Populasi dan Sampel}

Populasi adalah keseluruhan obyek (orang, kejadian, atau segala sesuatu yang mempunyai karakteristik tertentu) yang akan diteliti (Murni et.al. 2013). Sampel merupakan sebagian elemen-elemen populasi yang terpilih untuk diteliti (Murni et.al. 2013). Adapun populasi dalam penelitian ini adalah karyawan wanita berhijab.

Sedangkan sampel yang diambil dilakukan dengan teknik sampel puposive yaitu teknik penentuan sampel dengan pertimbangan tertentu (Sugiyono, 2009) Dalam melakukan penelitian ini penulis menyebarkan kuesioner sebanyak 100 lembar kuesioner dan yang dapat diolah 92 kuesioner. Dengan kriteria karyawan wanita yang berprofesi sebagai sales promotion girl (SPG) event, sudah menikah dan sebagai SPG minimal 1 (satu) tahun.

\section{Definisi Operasional Variabel}

Indikator serta variabel-variabel yang akan digunakan dalam penelitian ini perlu didefinisikan dengan untuk memberikan kejelasan maksud penelitian ini.

1. Internal locus of control : Menurut Robbins (2007:102) "internal locus of control adalah seseorang yakin bahwa mereka merupakan pemegang kendali atas apapun yang terjadi pada diri mereka". Internal locus of control terjadi bila seseorang percaya bahwa dirinya adalah tuan dari nasibnya sendiri. Orang dengan internal locus of control percaya bahwa mereka mengendalikan nasib mereka sendiri dan bertanggung jawab terhadap apa yang terjadi pada diri mereka sendiri. Indikatornya terdiri dari 3 item dari duffy et,al(1977).

2. Etika kerja islam merupakan orientasi yang membentuk dan memengaruhi keterlibatan dan partisipasi muslim di tempat kerja (Ali dan Owaihan, 2008). Indikator etika kerja islami 5 item dari Ali (1988).

3. Role Conflict, Role conflict didefinisikan sebagai "ketidak sesuaian dalam peranan yang telah dikomunikasikan sehingga berbenturan dengan peran yang dijalankan" (Rizzo et al., 1970) dalam Yousef (2000). Indikator 
pengukuran role conflict berdasarkan pada penelitian dari Rizzo et al.,(1970) terdiri dari 5 item.

Data kuesioner yang diperoleh diklasifikasikan dengan menggunakan skala Likert. Untuk menentukan nilai dan jawaban atas setiap pertanyaan dalam kuesioner digunakan skala Likert 5 poin yaitu : Sangat setuju (5); Setuju (4); netral (3); tidak sejutu (2); dan sangat tidak setuju (1). Dalam penelitian ini hasil uji validitas dan reliabilitas menunjukkan hasil yang valid dan reliabel.

\section{Teknik Analisis Statistik}

Adapun teknik analisis yang digunakan untuk menguji dan membuktikan hipotesis dalam penelitian ini digunakan uji analisis dengan dua tahapan yaitu dengan regresi linear yaitu dengan bantuan SPSS versi 16 dan untuk uji pengaruh langsungnya (path analysis) uji sobel untuk menguji signifikansi variabel mediasinya.

\section{HASIL PENELITIAN DAN PEMBAHASAN \\ Hasil uji hipotesis}

H1: internal locus of control berpengaruh signifikan terhadap role conflict karyawan wanita berhijab

Untuk menjawab hipotesis pertama yang diajukan perlu dilakukan dilakukan Analisis Regresi Model 1 untuk mengetahui pengaruh dari variabel bebas (independent) terhadap variabel mediasi (intervening). Pada analisis regresi model 1 (satu) persamaan strukturalnya adalah:

$$
\begin{gathered}
\mathrm{RC}=\mathbf{a}+\mathbf{b} 1 \mathrm{ILC}+\mathbf{e} \\
\text { atau } \\
\mathrm{RC}=\mathbf{1 1 , 3 2 0}+\mathbf{0 , 8 1 9} \text { ILC }
\end{gathered}
$$

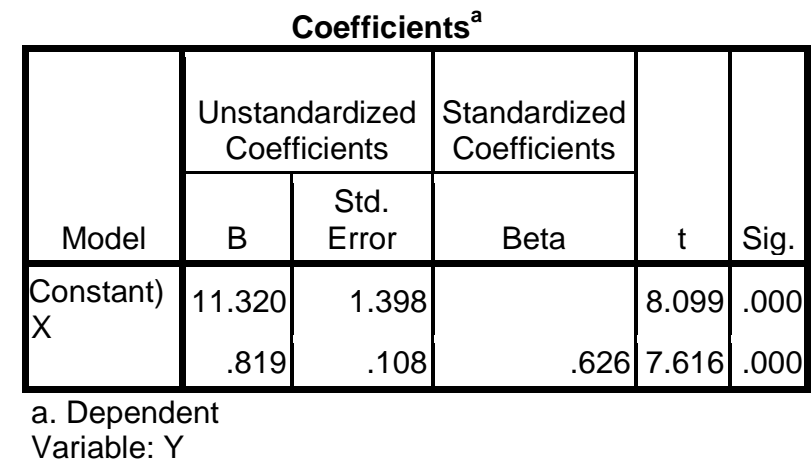

H2: internal locus of control berpengaruh signifikan terhadap etika kerja islam karyawan wanita berhijab

Analisis regresi model 2 (dua) digunakan untuk mengetahui kekuatan hubungan dari variabel bebas (independent) terhadap variabel terikat (dependent) . Pada analisis regresi model 2 rumus

\begin{tabular}{|c|c|c|c|c|c|}
\hline \multicolumn{6}{|c|}{ Coefficients $^{a}$} \\
\hline \multirow[b]{2}{*}{ Model } & \multicolumn{2}{|c|}{$\begin{array}{l}\text { Unstandardize } \\
\text { d Coefficients }\end{array}$} & \multirow{2}{*}{\begin{tabular}{|c|}
$\begin{array}{c}\text { Standardize } \\
\mathrm{d} \\
\text { Coefficients }\end{array}$ \\
Beta \\
\end{tabular}} & \multirow[b]{2}{*}{$\mathrm{t}$} & \multirow[b]{2}{*}{ Sig. } \\
\hline & B & $\begin{array}{l}\text { Std. } \\
\text { Error }\end{array}$ & & & \\
\hline $\begin{array}{l}\text { (Constant) } \\
\text { X }\end{array}$ & $\begin{array}{r}16.38 \\
3 \\
.438\end{array}$ & $\begin{array}{r}1.983 \\
.153\end{array}$ & .290 & $\begin{array}{r}8.26 \\
0 \\
2.87 \\
1\end{array}$ & $\begin{array}{l}.000 \\
.005\end{array}$ \\
\hline
\end{tabular}
persamaan strukturalnya adalah:

$$
\begin{gathered}
\text { EKI }=\mathbf{a}+\mathbf{b} 1 \mathbf{I L C}+\mathbf{e} \\
\text { atau } \\
\mathbf{E K I}=\mathbf{1 6 , 3 8 3}+\mathbf{0 , 4 3 8} \text { ILC }
\end{gathered}
$$

H3 : etika kerja Islam berpengaruh signifikan terhadap role conflict karyawan wanita berhijab 
Berdasarkan tabel pengujian koefisien regresi dapat diformulasikan sebagai berikut:

$$
\mathbf{R C}=\mathbf{a}+\mathbf{b 1 E K I}+\mathbf{e}
$$

\begin{tabular}{|c|c|c|c|c|c|}
\hline \multirow[b]{3}{*}{ Model } & \multicolumn{4}{|c|}{ Coefficients $^{\mathrm{a}}$} & \\
\hline & \multicolumn{2}{|c|}{$\begin{array}{c}\text { Unstandardized } \\
\text { Coefficients }\end{array}$} & \multirow{2}{*}{\begin{tabular}{|c|}
$\begin{array}{c}\text { Standardized } \\
\text { Coefficients }\end{array}$ \\
Beta \\
\end{tabular}} & \multirow[b]{2}{*}{$t$} & \multirow[b]{2}{*}{ Sig. } \\
\hline & B & $\begin{array}{l}\text { Std. } \\
\text { Error }\end{array}$ & & & \\
\hline $\begin{array}{l}\text { (Constant) } \\
Z\end{array}$ & $\begin{array}{r}13.691 \\
.373\end{array}$ & $\begin{array}{r}1.822 \\
.082\end{array}$ & .431 & $\begin{array}{l}7.512 \\
4.527\end{array}$ & $\begin{array}{l}.000 \\
.000 \\
\end{array}$ \\
\hline
\end{tabular}$$
\mathrm{RC}=13,691+0,373 \mathrm{EKI}
$$

a. Dependent

Variable: $Y$

H4 : internal locus of control berpengaruh signifikan terhadap role conflict karyawan wanita berhijab melalui etika kerja islam sebagai variabel intervening

$$
\text { Pada Penelitian ini }
$$

menggunakan uji sobel yang merupakan alat analisis untuk menguji signifikansi dari hubungan tidak langsung antara variabel independen dengan variabel dependen yang dimediasi oleh variabel mediator. Hasil perhitungan sobel test dengan menggunakan bantuan website

http://quantpsy.org/sobel/sobel.htm.

$$
\text { Dilakukan dengan }
$$

memasukkan nilai unstandardized coefficients Beta dari variabel independen pada hasil regresi pertama dan juga regresi yang kedua dengan nilai unstandardized

\begin{tabular}{|c|c|c|c|c|c|}
\hline \multirow[b]{2}{*}{ Model } & \multicolumn{2}{|c|}{$\begin{array}{l}\text { Unstandardized } \\
\text { Coefficients }\end{array}$} & \multirow{2}{*}{$\begin{array}{c}\begin{array}{c}\text { Standardized } \\
\text { Coefficients }\end{array} \\
\text { Beta }\end{array}$} & \multirow[b]{2}{*}{$\mathrm{t}$} & \multirow[b]{2}{*}{ Sig. } \\
\hline & B & $\begin{array}{l}\text { Std. } \\
\text { Error }\end{array}$ & & & \\
\hline \multirow{3}{*}{$\begin{array}{l}\text { (Constant) } \\
\text { X } \\
\text { Z }\end{array}$} & 7.463 & 1.757 & & 4.248 & .000 \\
\hline & .716 & .107 & .547 & 6.722 & .000 \\
\hline & .235 & .070 & .272 & 3.344 & .001 \\
\hline
\end{tabular}
coefficients Beta yang memediasi ditampilkan pada tabel berikut :
Coefficients $^{a}$

a. Dependent

Variable: $Y$

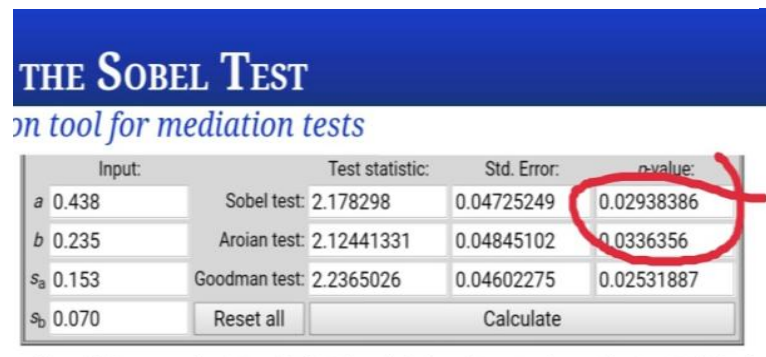

Alternatively, you can insert $t_{\mathrm{a}}$ and $t_{\mathrm{b}}$ into the cells below, where $t_{\mathrm{a}}$ and $t_{\mathrm{b}}$ are the $t$-test statistics for between the $a$ and $b$ coefficients and zero. Results should be identical to the first test, except for en rounding.

Berdasarkan hasil analisis menunjukkan bahwa keempat hipotesis yang diajukan diterima kebenarannya, namun hubungan antara etika kerja islam dan role conflict positif. Hal tersebut dimungkinkan terjadi karena responden merupakan SPG event yang tidak memiliki gaji tetap dan juga mereka sudah menikah.

Dimana mereka ketika mereka memiliki internal Locus of control yang tinggi maka mereka mempunyai etika kerja islam yang tinggi pula, namun role conflict mereka tinggi karena status mereka yang sudah menikah dan hanya SPG event.

\section{SIMPULAN DAN SARAN \\ Simpulan}

Dari hasil dan analisis serta pengujian yang telah dilakukan, maka diperoleh kesimpulan hasil penelitian bahwa keempat hipotesis yang diajukan diterima 
kebenarannya, namun hubungan antara etika kerja islam dan role conflict positif.

\section{Saran}

Adapun saran dalam hasil penelitian ini adalah :

1. Karyawan membutuhkan kepastian status dan reward untuk perkerjaan yang dijalaninya.

2. Untuk perusahaan memberikan kebebasan yang berkaitan dengan agamanya, misal diijinkan sholat atau memakai hijab.

3. Untuk mengurangi konflik peran perusahaan lebih memperhatikan tunjangan atau bonus yang diberikan.

\section{DAFTAR PUSTAKA}

Ali, Abbas, et,al (1998). "Scaling an Islamic Work Ethic", The Journal of Socyal Psychology. Vol 128 (5)

Ahmad Janan Asifudin, 2004. Etos Kerja Islami. Penerbit Universitas Muhammadiyah Surakarta.

Ahmad, Shukri and Owoyemi, Musaa Yusuf. 2012. The Concept of Islamic Work

Ethic : An Analysis of Some Salient Points in The Prophetic Traditional. International Journal of Business and Social Science, Vol.3 No.20 pp. 117

Miner, J.B., 1992. Industrial Organizational Psychology. New York : McGraw-Hill,Inc.
Mohamed, N., Karim, N.S.A., Husein, R (2010). "Linkng Islamic Work Ethics to Computer Use Ethics, Job Satisfaction, and Organizational Commitment in Malaysia”. Journal of Business System, Governance, and Ethics vol 5 no 1 pp 13-23.

Yousef, D.A. (2001). "Islamic Work Ethics - A Moderator Between Organizational Commitment and Job Satisfaction in a CrossCultural Context", Personal Review, Vol. 30 No.2

http://quantpsy.org/sobel/sobel.htm diakses tanggal 16 april 2017

https://stcmalang.wordpress.com/201 6/01/05/sobel-test-mengujipengaruh-tidak-langsung/ diakses tanggal 15 april 2017 Sumber

Dari-

$>$ http://wahdah.or.id/10kewajiban-seorang-muslimah/ . diakses tanggal 12 mei 2017 